\section{The Conformations of Discodermolide in DMSO}

Edith Monteagudo, ${ }^{\dagger}$ Daniel O. Cicero, ${ }^{\S}$ Ben Cornett," David C. Myles, ${ }^{\ddagger}$ and James P. Snyder*,I

Universidad Nacional de Quilmes Roque Sáenz Peña 180, Bernal, (1876)

Pcia. de Buenos Aires, Argentina Istituto di Richerche di Biologia Molecolare P. Angeletti 00040 Pomezia, Italy Department of Chemistry, Emory University Atlanta, Georgia 30322 Chiron Corporation, Emeryville, California 94608

Received January 22, 2001 Revised Manuscript Received May 8, 2001

(+)-Discodermolide (1), a polyhydroxylated lactone isolated from the marine sponge Discodermia dissoluta, ${ }^{1}$ is currently a high-profile substance for its promise as an immunosuppressive agent ${ }^{1,2}$ and an anti-cancer drug. The compound induces apoptosis in human breast cancer cells, ${ }^{3}$ inhibits the in vitro proliferation of murine P388 leukemia cells, ${ }^{1}$ and combines synergistically with Taxol to suppress the proliferation of human carcinoma cells. ${ }^{4}$ Biomechanistically, discodermolide resembles Taxol and epothilone in its ability to bind to microtubules, effect tubulin polymerization, and promote mitotic arrest. ${ }^{5}$ Not surprisingly, these optimistic findings have stimulated a number of laboratories to pursue the total synthesis of the compound. ${ }^{6,7}$

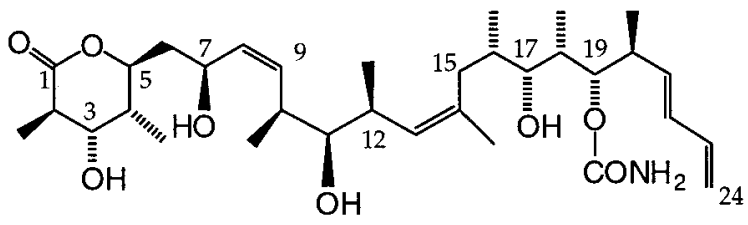

(+)- Discodermolide, 1

Reports that discodermolide binds stoichiometrically to microtubules and competitively blocks Taxol binding to the same protein assemblage ${ }^{5}$ have encouraged the supposition that there is a common $\beta$-tubulin (TB) binding pocket for compounds capable of promoting tubulin polymerization. Several groups have developed common pharmacophores on this basis. ${ }^{8}$ While the electron crystallography structure of the discodermolide-TB complex is under active investigation, ${ }^{9,10}$ an understanding of the dynamic properties of the molecule in solution has the potential to provide valuable insights into the binding conformation. This

\footnotetext{
$\dagger$ Universidad Nacional de Quilmes.
}

$\S$ Istituto di Richerche di Biologia Molecolare P. Angeletti.

$¥$ Chiron Corporation

"Emory University.

(1) Gunasekera, S. P.; Gunasekera, M.; Longley, R. E.; Schulte, G. K. J. Org. Chem. 1990, 55, 4912-4915. Gunasekera, S. P.; Gunasekera, M. Longley, R. E.; Schulte, G. K. J. Org. Chem. 1990, 55, 1346.

(2) Longley, Ross E.; Gunasekera, Sarath P.; Faherty, Denise; McLane, John; Dumont, Francis. Ann. N.Y. Acad. Sci. 1993, 696, 94-107.

(3) (a) Balachandran, R.; Grant, S. G.; Welsh, M. J.; Day, B. W. Breast J. 1998, 4, 409-419. (b) Balachandran, R.; Ter Haar, E.; Welsh, M. J.; Grant, S. G.; Day, B. W. Anti-Cancer Drugs 1998, 9, 369-370.

(4) (a) Martello, L. A.; McDaid, H. M.; Regl, D. L.; Yang, C.-P. H.; Meng, D.; Pettus, T. R. R.; Kaufman, M. D.; Arimoto, H.; Danishefsky, S. J.; Smith A. B., III; Horwitz, S. B. Clin. Cancer Res. 2000, 6, 1978-1987. (b) Giannakakou P.; Fojo, T. Clin Cancer Res. 2000, 6, 1613-1615.

(5) (a) Hung, D. T.; Nerenberg, J. B.; Schreiber, S. L. J. Am. Chem. Soc. 1996, 118, 11054-11080. (b) Hung, D. T.; Chen, J.; Schreiber, S. L Chem. Biol. 1996, 3, 287-293. (c) ter Haar, E.; Kowalski, R. J.; Hamel, E.; Lin, C. M.; Longley, R. E.; Gunasekera, S. P.; Rosenkranz, H. S.; Day, B. W. Biochemistry 1996, 35, 243-50. (d) Kowalski, R. J.; Giannakakou, P.; Gunasekera, S. P.; Longley, R. E.; Day, B. W.; Hamel, E. Mol. Pharmacol. 1997, 52, 613-622. has proven to be the case for both Taxol and epothilone, where minor to moderate contributors to the solution conformer populations have surfaced as novel candidates for ligand binding to $\beta$-TB. ${ }^{10-12}$ In the present report, we describe a high-field 2-D NMR analysis of $(+)$-discodermolide ${ }^{6,13}$ followed by a NAMFIS analysis (NMR analysis of molecular flexibility in solution) $)^{14,15}$ of the data to deconvolute the averaged NMR spectrum into a collection of conformer populations. Three dominant families emerge from the analysis.

Apart from lactone ring and $\mathrm{C}-\mathrm{OH}$ isomerism, the acyclic $\mathrm{C} 5-$ C24 fragment of discodermolide presents 15 single bonds. Were each of the five Csp2-Csp3 and nine Csp3-Csp3 attachments able to adopt two and three conformations, respectively, a little over 600000 local minima would result. Fortunately, the rotational freedom of many of the single bonds is attenuated by the 10 tertiary centers along the $\mathrm{C} 5-\mathrm{C} 24$ backbone. Nonetheless, a nontrivial number of conformers can be expected to contribute to the observable NMR average, while an even greater number with mole fractions less than $1 \%$ are undoubtedly accessible by torsional interchange under appropriate conditions of solvent, temperature, and induced selection.

In a preliminary attempt to identify the major forms that contribute to the discodermolide average in DMSO at ambient temperatures, we have intersected the averaged NMR-derived distances and $\mathrm{H}-\mathrm{H}$ coupling constants (see Tables 1 and 2, Supporting Information) with the same variables across a range of 1186 fully optimized MMFF(94)/GBSA/ $\mathrm{H}_{2} \mathrm{O}^{16}$ discodermolide conformations. ${ }^{17}$ Conformer deconvolution via the NAMFIS protocol delivered 14 "best fit" conformations (Table 3) that, like

(6) Total syntheses: (a) Nerenberg, J. B.; Hung, D. T.; Somers, P. K.; Schreiber, S. L. J. Am. Chem. Soc. 1993, 15, 12621-12622. (b) Smith, A B., III; Qiu, Y.; Jones, D. R.; Kobayashi, K. J. Am. Chem. Soc. 1995, 117, 12011-12012. (c) Harried, S. S.; Yang, G.; Strawn, M. A.; Myles, D. C. J. Org. Chem. 1997, 62, 6098-6099. (d) Marshall, J. A.; Johns, B. A. J. Org. Chem. 1998, 63, 7885-7892. (e) Smith, A. B., III; Kaufman, M. D.; Beauchamp, T. J.; LaMarche, M. J.; Arimoto, H. Org. Lett. 1999, 1, 18231826. (f) Paterson, J.; Florence, G. J.; Gerlach, K.; Scott, J. Angew. Chem., Int. Ed. 2000, 39, 377-380. (g) Paterson, I.; Florence, G. J. Tetrahedron Lett. 2000, 41, 6935-6939. (h) Smith, A. B., III; Beauchamp, T. J.; LaMarche, M. J.; Kaufman, M. D.; Qiu, Y.; Arimoto, H.; Jones, D. R.; Kobayashi, K. J. Am. Chem. Soc. 2000, 122, 8654-8664.

(7) Partial syntheses: (a) Clark, D. L.; Heathcock, C. H. J. Org. Chem 1993, 58, 5878-5879. (b) Golec, J. M. C.; Jones, S. D. Tetrahedron Lett. 1993, 34, 8159-8162; 8163-8166. (c) Miyazawa, M.; Oonuma, S.; Maruyama, K.; Miyashita, M. Chem. Lett. 1997, 12, 1191-1192; 1193-1194. (d) Arefolov, A.; Panek, J. S. Presented at the 216th National Meeting of the American Chemical Society, Boston, MA, August 23-27, 1998; Paper ORGN661. (e) Misske, A. M.; Hoffmann, H. M. R. Tetrahedron 1999, 55, 43154324. (f) Evans, D. A.; Halstead, D. P.; Allison, B. D. Tetrahedron Lett. 1999, 40, 4461-4462.

(8) (a) Snyder, J. P. Presented at the Alfred Benzon Symposium 42, Copenhagen, Denmark, June 8-12, 1997; abstracts. (b) Snyder, J. P.; Xia, X.; Schestopol, M. A.; Kim, Y.; Bray, D.; Cain, M.; Liotta, D.; Koehler, K. F.; Jansen, J. M. In Rational Molecular Design in Drug Research; Liljefors, T., Jørgensen, F. S., Krogsgaard-Larsen, P., Eds.; Munksgaard: Copenhagen, 1998; pp 115-135. (c) Ojima, I.; Chakravarty, S.; Inoue, T.; Lin, S.; He, L.; Horwitz, S. B.; Kuduk, S. D.; Danishefsky, S. J. Proc. Natl. Acad. Sci. U.S.A 1999, 96, 4256-4261. (d) Bhonsle, J. B.; Avery, M. A. Presented at the 218th American Chemical Society National Meeting, New Orleans, Aug. 22-26, 1999; COMP-094.

(9) Nogales, E.; Wolf, S. G.; Downing, K. H. Nature 1998, 391, 199203.

(10) Li, H.; Downing, K. H.; Nettles, J. H.; Nevins, N.; Snyder, J. P. unpublished.

(11) Snyder, J. P.; Nevins, N.; Cicero, D. O.; Jansen, J. J. Am. Chem. Soc 2000, 122, 724-725.

(12) Snyder, J. P.; Nettles, J. H.; Cornett, B.; Downing, K. H.; Nogales, E. Proc. Nat. Acad. Sci. U.S.A. 2001, 98 (19), 5312-5316.

(13) Myles, D. et al., manuscript in preparation.

(14) Cicero, D. O.; Barbato, G.; Bazzo, R. J. Am. Chem. Soc., 1995, 117, $1027-1033$

(15) Nevins, N.; Cicero, D.; Snyder, J. P. J. Org. Chem. 1999, 64, 39793986.

(16) (a) Halgren, T. A.; Nachbar, R. B. J. Comput. Chem. 1996, 17, 587615. (b) Halgren, T. A. J. Comput. Chem. 1999, 20, 730-748. (c) cf. www.schrodinger.com/macromodel2.html.

(17) See the Supporting Information for details. 


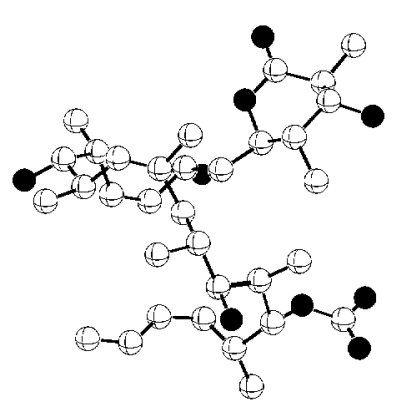

a

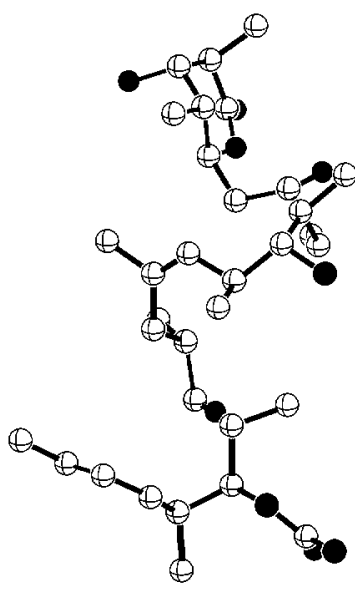

b

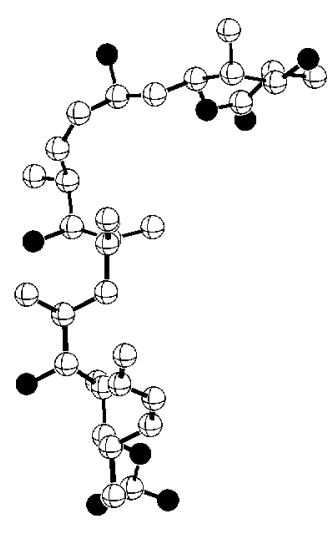

C

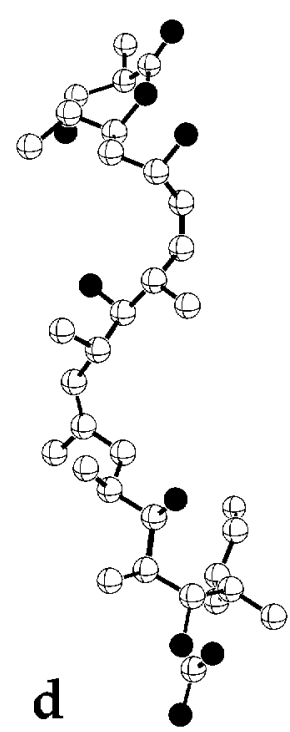

Figure 1. The X-ray structure and three conformational classes of discodermolide by MMFF/NAMFIS analysis of the 1D- and 2D NMR spectra in DMSO- $d_{6}$; (a) the X-ray conformation; (b) 4, the corkscrew form; (c) 3, the sickle motif, (d) 5, an extended or awl form.

those of Taxol, ${ }^{11}$ fall into three principal categories. The form most populated $(\mathbf{1}, \mathbf{2}, \mathbf{4}, \mathbf{6}, \mathbf{7}$, and $\mathbf{1 2}, 68 \%$ total) can be characterized as having a corkscrew shape (Figure 1b). The amide and allylic diene at C19 form the two ends of the "handle", while $\mathrm{C} 1-\mathrm{C} 18$ assumes an approximate left-handed helical shape. A sickle motif is adopted by the second largest family $(\mathbf{3}, \mathbf{8}, \mathbf{9}$, and 11, $21 \%$ total, Figure 1c). The third grouping includes a trio of extended or awl-like conformations $(\mathbf{5}, \mathbf{1 0}$, and 13, 10\% total; Figure 1d). One other conformation $(\mathbf{1 4}, 1 \%)$, a corkscrew with a right-handed helical twist, completes the set. Apart from the selected torsional angles given in Table 3, the distance between C5 and $\mathrm{C} 22$ is most characteristic of the classes: 7-10 (corkscrew), 9.5-11.5 (sickle), 13.5-16 ̊ (awl). For comparison, the variables of the single-crystal X-ray structure are depicted in Figure 1a (cf. Table 3). The helical solid-state conformation belongs to the first class, but as a compressed variation ( $r(\mathrm{C} 5-$ $\mathrm{C} 22)=6.3 \AA$ ). A Boltzmann distribution of the NAMFIS mole fractions at $298 \mathrm{~K}$ suggests a diminutive energy gap of $2.1 \mathrm{kcal} /$ mol (Table 3) across all three conformational classes

Examination of the crystal structure geometry in the context of the NMR-derived distances and dihedral angles might suggest it to be a reasonable single conformation match of the data. However, including it with either conformers 1-14 or the full set followed by a subsequent 15 or 1187 conformation NAMFIS analysis, respectively, illustrates that the structure contributes no more than $1 \%$ to the overall conformational average. Although mismatches between experimental and calculated ${ }^{18}{ }^{3} J(\mathrm{H}, \mathrm{H})$ coupling constants are no greater than $2.5 \mathrm{~Hz}$, the structure violates nine NOE distance constraints by $0.8-1.8 \AA$. Likewise, a number of key cross-peaks that should appear from the X-ray structure are missing. A basis for the absence of the X-ray form in DMSO is suggested by inspection of the crystal coordinates in the unit cell. Individual structures sustain no intramolecular H-bonds, although they contact other copies through a small number of bridging waters. Thus, intramolecular clustering of the multiple hydrophobic centers appears to cause compression in

(18) Haasnoot, C. G. G.; De Leeuw, F. A. A. M.; Altona, C. Tetrahedron 1980, 36, 2783-2792. the solid state. DMSO solvation of the widely spaced $\mathrm{OH}$ and NH groups in $\mathbf{1}$ apparently counters the latter.

One additional interesting feature of the 14 bond-rotation isomers concerns the conformation of the six-membered lactone ring. The stereochemistry of the latter permits two axial and two equatorial substituents for the ring as a chair, but four equatorial placements for the twist or boat form. In the crystal, the lactone adopts a slightly twisted boat shape with all pendant groups equatorial. In the current model, only conformers $3,5-7$, and 14 express twist lactones, while the remaining nine adopt the classic flattened chair motif.

We conclude that, in solution at $298 \mathrm{~K}$, the flexibility of discodermolide is expressed as a rapidly interconverting mixture of over 10 conformations. In the present model of 14 conformers, three separate families emerge. In order of decreasing population, they are the corkscrew, the sickle, and the awl motifs. The singlecrystal X-ray structure belongs to the corkscrew family. It can be anticipated that any single conformation matching the NMR geometric average with a high degree of accuracy will do so at the expense of an energetically costly structural deformation, in other words, by targeting a virtual conformation. ${ }^{11,19}$ The NMR structure of discodermolide very recently determined by Smith, LaMarche, and Falcone-Hindley ${ }^{20}$ may fall into this category.

Acknowledgment. We are thankful to Amos Smith (University of Pennsylvania) for alerting us to the University of Pennsylvania NMR work prior to publication and to Dennis Liotta (Emory Univeristy) for support and encouragement.

Supporting Information Available: NMR conditions, computational details, and ${ }^{1} \mathrm{H}{ }^{3} \mathrm{~J}(\mathrm{H}, \mathrm{H})$ 's and NOE-derived distances (Tables $1-3$ ) for discodermolide (PDF). This material is available free of charge via the Internet at http://pubs.ac.org.

\section{JA015569U}

(19) (a) Jardetzky, O. Biochim. Biophys. Acta 1980, 621, 227-232. (b) Jardetzky, O.; Roberts, G. C. K. NMR in Molecular Biology; John Wiley \& Sons: New York, 1986; pp 126-140.

(20) Smith, A. B., III; LaMarche, M. J.; Falcone-Hindley, M. Org. Lett. 2001, 3, 695-698. 